\title{
POU3F2 Gene
}

National Cancer Institute

\section{Source}

National Cancer Institute. POU3F2 Gene. NCI Thesaurus. Code C98197.

This gene is involved in both transcriptional regulation and cell proliferation. 